\title{
Comparison of sickness absence in Belgian, German, and Dutch firms
}

\author{
R PRINS AND A DE GRAAF \\ From the CCOZ Foundation, $1083 \mathrm{HJ}$ Amsterdam, the Netherlands
}

ABSTRACT International comparisons of sickness absence rates are difficult to make because of different national social security arrangements or recording procedures. Therefore a cross national study of sickness absence in Belgium, West Germany, and the Netherlands focused firstly on "contextual" aspects of sickness absence such as work incapacity benefit schemes, job security regulations, and the role of occupational physicians. Substantial differences were observed in regulations, local definitions, and available data. Those differences provide hypotheses for possibly divergent absence levels as well. For instance, Belgium shows the most diversified control procedures, the lowest level of sickness benefits, and the most rigid qualifying criteria for invalidity benefits. Sickness absence data were obtained from companies of four different clusters, each consisting of a comparable Belgian, German, and Dutch organisation. Conceptual, administrative, and statistical sources of bias were accounted for by selecting companies which resemble each other as to their product, production process, size, and geographical location: by using standardised definitions, absence data, and indices (observation period 1 January 1980 to 1 January 1982); and by measuring population variables to eliminate obvious explanations in terms of workforce composition. Controlled comparisons in these multiple clusters showed considerable and consistent differences in sickness absence rates. Whereas Belgian employees had 20.3 days of sickness absence (standardised for sex, age, and occupation) a year, German and Dutch employees had $28 \cdot 5$ and 39.1 days off a year respectively. Factors that might account for these differences are discussed.

Dutch sickness absence rates doubled in 20 years and showed their highest level in 1978 and 1979. From then on the rates have decreased substantially, a fall that appears to have continued into 1984 . The number of disability beneficiaries with permanent invalidity increased in 1982 to $15 \%$ of the labour force, but recently the increase has moderated. ${ }^{1}$ Table 1 shows the trends in these related phenomena. Sickness absence includes all spells of work incapacity due to illness, accident, or confinement, with a maximum duration of 365 calendar days. The number of invalidity recipients includes those who qualified for the invalidity benefit scheme after a fixed period of sickness benefit ( 52 weeks).

The economic and sociomedical concern with increasing sickness absence and invalidity rates has given rise to several investigations in the past two decades (nearly all published in Dutch, however). In the extensive research on sickness absence and invalidity attention has recently focused on psycho-

Accepted 18 November 1985 logical aspects, ${ }^{4}$ organisational factors, ${ }^{56}$ and determinants in the social security and health care system. ${ }^{7-9}$

In the debate on sickness absence it has sometimes been argued that Dutch rates are higher than those in other West European countries. Indeed, some recent studies suggest unanimously that employees in the Netherlands and Sweden show the highest sickness absence rates compared with employees in other industrialised countries ${ }^{10-13}$ (table 2).

These international reviews of crude aggregated data from social security administrations, industrial statistics, or household interviews have serious limitations, however. Most earlier studies, ${ }^{14-18}$ with the exception of those by Taylor, ${ }^{1617}$ failed to verify whether the data were sufficiently equivalent as to their definitions, scope, and measurement-for instance, the rates set out in the first two columns of table 2 for West Germany show a remarkable difference in the percentage of days lost. It seems unlikely that this is only caused by the subsequent years of observation. Apparently the definition and 529 
Table 1 Sickness absence rates and number of invalidity benefit recipients in the Netherlands $(1964,1969,1974$, 1979, 1984)

\begin{tabular}{|c|c|c|c|c|c|c|c|}
\hline \multirow[t]{3}{*}{ Year } & \multicolumn{6}{|c|}{ Sickness absence } & \multirow{3}{*}{$\begin{array}{l}\text { Invalidity } \\
\text { No of recipients }\end{array}$} \\
\hline & \multicolumn{3}{|l|}{ Male } & \multicolumn{3}{|l|}{ Female } & \\
\hline & $\begin{array}{l}\text { Days per } \\
\text { person }\end{array}$ & $\begin{array}{l}\text { Spells per } \\
\text { person }\end{array}$ & $\begin{array}{l}\text { Duration per } \\
\text { spell }\end{array}$ & $\begin{array}{l}\text { Days per } \\
\text { person }\end{array}$ & $\begin{array}{l}\text { Spells per } \\
\text { person }\end{array}$ & $\begin{array}{l}\text { Duration per } \\
\text { spell }\end{array}$ & \\
\hline $\begin{array}{l}1964 \\
1969 \\
1974 \\
1979 \\
1984\end{array}$ & $\begin{array}{l}21 \cdot 5 \\
28 \cdot 1 \\
31 \cdot 8 \\
35 \cdot 4 \\
25 \cdot 2\end{array}$ & $\begin{array}{l}1.43 \\
1.75 \\
1.84 \\
1.97 \\
1.72\end{array}$ & $\begin{array}{l}15 \cdot 0 \\
16 \cdot 2 \\
17 \cdot 3 \\
17.9 \\
14 \cdot 7\end{array}$ & $\begin{array}{l}20 \cdot 4 \\
29 \cdot 6 \\
38 \cdot 7 \\
43 \cdot 8 \\
33 \cdot 6\end{array}$ & $\begin{array}{l}2.08 \\
2.47 \\
2.84 \\
3.05 \\
2.70\end{array}$ & $\begin{array}{r}9.9 \\
11 \cdot 8 \\
13 \cdot 6 \\
14.3 \\
12 \cdot 4\end{array}$ & $\begin{array}{l}\overline{194.000} \\
313.000 \\
622.000 \\
751.000\end{array}$ \\
\hline
\end{tabular}

Sources: sickness absence rates ${ }^{2}$ and invalidity rates. ${ }^{3}$

Days per person = average annual number of calendar days lost due to sickness absence per person year.

Spells per person $=$ average annual number of spells per person year.

Duration per spell $=$ average number of calendar days per spell.

measurement of sickness absence, or the observed populations at risk, are not identical, which may considerably affect the interpretation.

The data in table 2 illustrate a second limitation of sickness absence rates-namely, their statistically crude nature. They express only the mean level of absences in a population and do not give information about the nature of the absence (the frequency and duration, for example) or the population characteristics such as branch of industry, age distribution, or sex ratio. This lack of differentiation restricts the opportunity for adjusting the available data for comparative analysis by standardisation techniques. Comparative studies confined to this type of data may probably show some general trends in international sickness absence rates but leave much room for speculation.

\section{Objectives}

The present comparative study of sickness absence in the Netherlands and its neighbouring countries intended to avoid so far as possible the methodological and statistical constraints mentioned above. Initially the study was nothing more than an orientation to ascertain whether or not our problem

Table 2 Sickness absence rates (mostly: lost work time percentages) in some industrialised countries 1978, 1981, and 1983. Data from several sources ${ }^{10-13}$

\begin{tabular}{llccc}
\hline & $1978^{10}$ & $\begin{array}{c}1978^{11} \\
\left({ }^{*} 1979\right)\end{array}$ & $1981^{12}$ & $1983^{13}$ \\
\hline Great Britain & 8.0 & - & $\overline{7}$ & $\overline{7}$ \\
West Germany & 5.6 & $7 \cdot 7^{*}$ & 7.5 & -7 \\
France & 6.0 & $8 \cdot 3$ & 7.6 & $\overline{9} \cdot 5$ \\
The Netherlands & 9.2 & $12.0^{*}$ & 9.5 & 9.4 \\
Italy & - & 10.6 & 9.9 & 13.8 \\
Sweden & - & 13.8 & 13.5 & 3.2 \\
United States & - & 3.5 & 3.3 & 1.5 \\
Japan & - & $2.0^{*}$ & 1.6 & \\
\hline
\end{tabular}

was imaginary. To that end it focused on the conceptual, administrative, and statistical factors that may affect the comparability of international sickness $\circ$ absence data. In so far as these factors (sources of bias) could be controlled for, the investigation then aimed to explore differences in the level and structure of sickness absence by comparing sickness absence $\frac{\vec{C}}{\omega}$ rates in some clusters, each consisting of a similar Belgian, German, and Dutch organisation. The choice $\stackrel{\oplus}{\mathscr{Q}}$ of countries was not merely determined by theoretical or methodological considerations (similar sociocultural situation; divergent income maintenance schemes, and job security arrangements) but also by research conditions (budget, language, international contacts, and cooperation).

The comparative analysis was preceded by $a \stackrel{2}{\Rightarrow}$ research study of some "contextual" aspects of sick-을 ness absence in each country. To begin with, the various social security programmes and procedures for incapacity due to sickness, industrial accidents, or invalidity were compared for factors such as work $\stackrel{\oplus}{\mathcal{D}}$ incapacity concept, eligibility, level of benefits, medical certification, and rehabilitation. Secondly, those 3 regulations that apply to other risks such as unemployment or retirement and which are mutually dependent on health risks schemes were also examined. Finally, the position regarding job protection in 의 relation to sickness absence and the statutory role of $\frac{D}{O}$ the industrial physician vis-à-vis sickness absence were compared.

\section{Contextual aspects}

The investigations showed the existence of consid erable differences in the structure, executive pro- $\frac{\mathbb{\Phi}}{\Phi}$ cedures, and benefit level of social security regulations? in the three countries under study. ${ }^{19} \mathrm{~A}$ summary of 0 the findings is presented in table 3.

In 1967 the Dutch work incapacity and invalidity 
Table 3 Characteristic of sickness payment arrangements and invalidity benefit programmes in Belgium, West Germany, and the Netherlands in 1980 and 1981

\begin{tabular}{|c|c|c|c|}
\hline Characteristic & Belgium & Germany & Netherlands \\
\hline Medical certification & First day of work incapacity & First day (manual) or third day & None \\
\hline Surveillance and medical examination & $\begin{array}{l}\text { Medical officer from fund or } \\
\text { on behalf of employer }\end{array}$ & $\begin{array}{l}\text { Independent medical officer } \\
\text { on request of fund }\end{array}$ & \multirow{4}{*}{$\begin{array}{l}\text { Lay sick visitor and medical } \\
\text { officer of fund } \\
\text { Statutory } 2 \text { but suspended in } \\
\text { collective labour agreements } \\
80 \% \text {, but collective labour } \\
\text { agreements provide } 100 \% \\
\text { From 1st day of work incapacity }\end{array}$} \\
\hline Waiting days & One (payable after two weeks) & None & \\
\hline Level of sickness benefit ( $\%$ of earnings) & $60 \%$ & $80 \%$ & \\
\hline Payment of statutory sickness benefit & $\begin{array}{l}\text { After } 1 \text { week (wage earners) or } \\
1 \text { month (salaried employees) } \\
\text { in which employer pays } 100 \% \\
\text { of earnings }\end{array}$ & $\begin{array}{l}\text { After } 6 \text { weeks in which } \\
\text { employer pays } 100 \% \text { of } \\
\text { earnings }\end{array}$ & \\
\hline $\begin{array}{l}\text { Maximum period of sickness benefit } \\
\text { Minimal reduction of work capacity for } \\
\text { invalidity eligibility }\end{array}$ & $\begin{array}{l}52 \text { weeks } \\
66 \%\end{array}$ & $\begin{array}{l}78 \text { weeks } \\
50 \%\end{array}$ & $\begin{array}{l}52 \text { weeks } \\
15-25 \%\end{array}$ \\
\hline Level of invalidity benefits ( $\%$ of earnings) & $\begin{array}{l}43.5 \% \text { or } 66 \% \text { if there are } \\
\text { dependents }\end{array}$ & $15-80 \%$ & $10-80 \%$ \\
\hline
\end{tabular}

programme abandoned the "causality principle." No distinction is now made between sickness and injury, both are covered by the same income maintenance programmes and are paid for equally. Another, sociologically, striking feature is that the distinction made in Belgium and West Germany between wage earners ("blue collar") and salaried employees ("white collar") is lacking in the Netherlands.

Further comparison suggests that sickness absence has more financial consequences for Belgian and German employers than for their Dutch colleagues, since normal payment of full wage is continued during the first weeks. Employees in these countries experience financial consequences as well: severe (lasting) work incapacity inevitably causes reduction of income.

As Dutch general practitioners fear certification may damage the doctor patient relation, procedures for assessing work incapacity differ from those in the neighbouring countries. Instead of certification at the onset, evidence of incapacity is obtained during the period of absence through surveillance by lay inspectors and from medical examination by social security doctors.

Invalidity benefit schemes show substantial differences in their eligibility criteria and level and duration of benefit payment. The Dutch programme has the least rigid qualifying conditions. Therefore partially incapacitated Dutch workers do not fear the threat of being forced to claim unemployment benefits if they do not fully satisfy conditions of entitlement as opposed to similar workers in both neighbouring countries.

Finally, Belgian and German occupational physicians do not concern themselves with absent employees. Their Dutch collegues, however, accept an advisory role towards employees and management. About $50 \%$ of Dutch occupational physicians combine occupational health care and social security tasks.
Comparisons indicate that, with regard both to social security schemes and job protection rights, the conditions are most favourable for the Dutch employees and least favourable for the Belgian. This applies both to such aspects as wage benefit ratios, legitimation and verification of work incapacity, qualifying conditions for invalidity benefit schemes, and legal rules that permit dismissal for employees with frequent or long term sickness absence.

\section{Methods}

\section{SELECTION OF CASES}

The research plan aimed at a multiple comparison of sickness absence on the organisation level. The reason for making comparisons between factories is based on several facts: (1) the lack of adequate national statistics on sickness absence in Belgian employees; (2) basic data appropriate for standardised measurement of all types of sickness absence are available only in attendance records kept by organisations; and (3) company records contain data on several variables of the population at risk that are relevant for further statistical analysis.

Furthermore, the research plan focuses on a controlled comparison within a multiple case design. Organisations were selected that were matched on the basis of their product and type of technology, and so far as possible matched on their size and geographical location (urban or agricultural region). Another criterion for selection considered the data the company had to be able to provide for calculating strictly comparable sickness absence rates. As Smelser points out, by matching the organisations, resemblances are "ruled out" as explanatory factors, and explanations based on other variables may be examined. ${ }^{20}$

Multinational enterprises, employers' organisations, and local social scientists provided the names 
Table 4 Main characteristics of the clusters

\begin{tabular}{|c|c|c|c|c|c|c|c|}
\hline Cluster & Organisation & $\begin{array}{l}\text { Average } \\
\text { population } \\
\text { (person years) }\end{array}$ & $\begin{array}{l}\text { Female } \\
\text { employees (\%) }\end{array}$ & $\begin{array}{l}\text { Migrant } \\
\text { workers (\%) }\end{array}$ & $\begin{array}{l}\text { White collar } \\
(\%)\end{array}$ & $\begin{array}{l}\text { Average age } \\
\text { (years) }\end{array}$ & $\begin{array}{l}\text { Shiftworkers } \\
(\%)\end{array}$ \\
\hline I Paint & $\begin{array}{l}\text { B1 } \\
\text { G1 } \\
\text { N1 }\end{array}$ & $\begin{array}{r}671 \\
1737 \\
1219\end{array}$ & $\begin{array}{l}18 \\
11 \\
15\end{array}$ & $\begin{array}{r}1 \\
10 \\
3\end{array}$ & $\begin{array}{l}36 \\
27 \\
83\end{array}$ & $\begin{array}{l}36 \\
43 \\
38\end{array}$ & $\begin{array}{r}0 \\
42 \\
7\end{array}$ \\
\hline II Margarine & $\begin{array}{l}\text { B2 } \\
\text { G2 } \\
\text { N2 }\end{array}$ & $\begin{array}{l}694 \\
839 \\
823\end{array}$ & $\begin{array}{r}11 \\
21 \\
9\end{array}$ & $\begin{array}{l}3 \\
8 \\
8 \\
3\end{array}$ & $\begin{array}{l}26 \\
26 \\
34 \\
32\end{array}$ & $\begin{array}{l}40 \\
44 \\
40\end{array}$ & $\begin{array}{l}61 \\
47 \\
55\end{array}$ \\
\hline III Frozen food & $\begin{array}{l}\text { B3 } \\
\text { G3 }\end{array}$ & $\begin{array}{r}299 \\
1195\end{array}$ & $\begin{array}{l}38 \\
52\end{array}$ & $\begin{array}{r}2 \\
26\end{array}$ & $\begin{array}{l}17 \\
17\end{array}$ & $\begin{array}{l}37 \\
39\end{array}$ & $\begin{array}{l}82 \\
66\end{array}$ \\
\hline & N3 & 663 & 8 & 10 & 21 & 40 & 78 \\
\hline IV Tins & B4 & 585 & 14 & 9 & 24 & 38 & 63 \\
\hline & N4 & 783 & 4 & 33 & 47 & 37 & 75 \\
\hline Total group & $\begin{array}{l}\mathbf{B} \\
\mathbf{G}\end{array}$ & $\begin{array}{l}2249 \\
3771\end{array}$ & $\begin{array}{l}17 \\
26\end{array}$ & $\begin{array}{r}4 \\
14\end{array}$ & $\begin{array}{l}27 \\
25\end{array}$ & $\begin{array}{l}38 \\
42\end{array}$ & $\begin{array}{l}46 \\
51\end{array}$ \\
\hline & $\mathbf{N}$ & 3488 & $\begin{array}{l}20 \\
10\end{array}$ & $\begin{array}{l}14 \\
11\end{array}$ & 51 & 39 & 47 \\
\hline
\end{tabular}

B = Belgium.

$\mathrm{G}=$ Germany.

$\mathrm{N}=$ Netherlands.

of firms that might potentially fulfil the fixed requirements. Twenty five firms were approached and described before a sufficient comparable number was found. A "suitable" organisation could be included only if in each of the two other countries a similar and cooperative organisation was found. Four international clusters from different economic branches were finally formed. Table 4 sets out the main characteristics of the clusters and the national groups. The four clusters are characterised by their product: paints/coatings, margarine, frozen foods, tins/cans respectively. The German factory of cluster four withdrew, so only two organisations were left.

Within each cluster products and production technology are similar; however, geographic location of the firms and organisation size vary in some clusters.

According to local data or "inside impressions" most of the participating factories do not show sickness absence rates that are atypically high or low for their branch of industry.

\section{DEFINITION OF SICKNESS ABSENCE}

In the preparatory stage of the investigation the definitions, recording procedures, and available statistical data on sickness absence were examined in each organisation to provide a basis for a uniform definition and a standardised method of data collection and calculation.

With regard to the definition of sickness absence three main differences between the practices in the Netherlands and both Germany and Belgian should be noticed. As mentioned before, company records and national statistics in the Netherlands lack a reliable differentiation between the causes of incapacity for work. The term sickness absence in our study therefore covers work incapacity due to illness, injury, confinement, or maternity leave. Secondly, the Dutch sickness benefit scheme does not require medical certification of work incapacity. Hence, for German and Belgian employees both certified and uncertified cases of work incapacity are covered by the definition as long as they are due to health problems. Finally, there are international variations in the maximum period of temporary work incapacity. In the Netherlands the maximum duration of a spell of sickness absence is defined and recorded as one year (365 calendar days). By selecting data from individual absence records conforming to this operational definition, it was ensured that exactly the same types of absences were measured in all firms.

\section{DA T A}

Taking into account various sources of bias, it was necessary to collect the basic data on sickness absence directly from the records maintained by the organisations. For each spell of sickness absence two dates were recorded: the first day of work incapacity and the day on which work was resumed.

A small group of employees (trainees and temporary employees, for example) was excluded from the analysis. For each member of the defined population at risk some sociodemographical and work characteristics were collected: date of birth, date of enrolment, date and reason for leaving the firm, sex, occupational status (manual worker/staff employee), type of shift, wage group, nationality, and section (department). The sickness absence data and population variables were collected manually or by computertape over a two year observation period (1 January 1980 to 1 January 1982).

This extensive collection of data provided information on sickness absence in 1980 and 1981 for 11127 employees in 11 companies in the three countries under study. 
Table 5 Mean annual number of sickness absence days per person year in four clusters for 1980 and 1981

\begin{tabular}{|c|c|c|c|c|c|c|c|c|c|c|c|}
\hline \multirow{3}{*}{$\begin{array}{l}\text { Country } \\
\\
\text { Belgium } \\
\text { Germany }\end{array}$} & \multicolumn{10}{|c|}{ Days per index person } & \multirow[t]{2}{*}{ No of subjects } \\
\hline & \multicolumn{2}{|c|}{ Cluster 1} & \multicolumn{2}{|c|}{ Cluster 2} & \multicolumn{2}{|c|}{ Cluster 3} & \multicolumn{2}{|c|}{ Cluster 4} & \multicolumn{2}{|c|}{ National group } & \\
\hline & $\begin{array}{l}20 \cdot 1 \\
26 \cdot 6 \\
22 \cdot 6\end{array}$ & $\begin{array}{l}100 \\
132 \\
112\end{array}$ & $\begin{array}{l}19 \cdot 3 \\
35 \cdot 8 \\
30 \cdot 7\end{array}$ & $\begin{array}{l}100 \\
185 \\
159\end{array}$ & $\begin{array}{l}26 \cdot 3 \\
36 \cdot 1 \\
42 \cdot 0\end{array}$ & $\begin{array}{l}100 \\
137 \\
160\end{array}$ & $\frac{21 \cdot 2}{43 \cdot 4}$ & $\frac{100}{205}$ & $\begin{array}{l}21 \cdot 2 \\
31.4 \\
32.9\end{array}$ & $\begin{array}{l}100 \\
148 \\
155\end{array}$ & $\begin{array}{l}2245 \\
3732 \\
3498\end{array}$ \\
\hline
\end{tabular}

Table 6 Average annual sickness absence rates in the Belgian, West German, and Dutch groups for 1980 and 1981

\begin{tabular}{llllllll}
\hline National group & No of subjects & $\begin{array}{l}\text { Days per } \\
\text { person }\end{array}$ & Index & $\begin{array}{l}\text { Spells per } \\
\text { person }\end{array}$ & Index & $\begin{array}{l}\text { Duration per } \\
\text { spell }\end{array}$ & $\begin{array}{l}\text { Index } \\
\text { Belgium }\end{array}$ \\
Germany & 2245 & $21 \cdot 2$ & 100 & 1.40 & 100 & $14 \cdot 6$ & 100 \\
Netherlands & 3732 & 31.4 & 148 & $1 \cdot 89$ & 135 & 16.1 & 110 \\
\hline
\end{tabular}

Table 7 Average annual sickness absence rates in male and female employees from the Belgian, West German, and Dutch group for 1980 and 1981

\begin{tabular}{|c|c|c|c|c|c|c|c|}
\hline National group & No of subjects & $\begin{array}{l}\text { Days per } \\
\text { person }\end{array}$ & Index & $\begin{array}{l}\text { Spells per } \\
\text { person }\end{array}$ & Index & $\begin{array}{l}\text { Duration per } \\
\text { spell }\end{array}$ & Index \\
\hline $\begin{array}{l}\text { Men } \\
\text { Belgium } \\
\text { Germany } \\
\text { Netherlands } \\
\text { Women } \\
\text { Belgium } \\
\text { Germany } \\
\text { Netherlands }\end{array}$ & $\begin{array}{r}1859 \\
2762 \\
3132 \\
\\
386 \\
969 \\
346\end{array}$ & $\begin{array}{l}19.0 \\
28.8 \\
32.5 \\
31.4 \\
38.7 \\
34.7\end{array}$ & $\begin{array}{l}100 \\
152 \\
171 \\
100 \\
123 \\
111\end{array}$ & $\begin{array}{l}1 \cdot 31 \\
1.77 \\
2.08 \\
1 \cdot 77 \\
2.27 \\
2.69\end{array}$ & $\begin{array}{l}100 \\
135 \\
159 \\
\\
100 \\
128 \\
152\end{array}$ & $\begin{array}{l}14 \cdot 1 \\
15 \cdot 8 \\
15 \cdot 8 \\
16.7 \\
16 \cdot 7 \\
12.9\end{array}$ & $\begin{array}{r}100 \\
112 \\
112 \\
100 \\
100 \\
77\end{array}$ \\
\hline
\end{tabular}

\section{Main results}

Within each cluster the population variables measured basic sickness absence indices and their mutual relation was inspected. Substantial and fairly consistent differences were observed in the sickness absence rates of employees in the three countries. These differences are due neither to administrative nor statistical conditions, nor to remarkable variations in sociodemographical or work characteristics of the populations. ${ }^{21}$ Some of the findings are presented here in the form of aggregated data from the three national groups, since they reflect to a large extent the patterns and differences identified in the four separate case studies (table 5).

The specific sickness absence measures used are: the severity rate (average annual number of calendar days of sickness absence per person year), the frequency rate (average annual number of new spells per person year), and the average duration (average annual number of calendar days per spell). As Belgian employees generally show the lowest rates, they have been selected as the base of the index to facilitate comparison.

INTERNATIONAL DIFFERENCES

Table 5 shows the mean annual number of calendar days of sickness absence per person year for 1980 and 1981 in the four international groups. Within each cluster Belgian employees show the lowest rates of absence. The German and Dutch figures are appreciably higher but they do not show a consistent rank order. This is shown in the fifth column (aggregated data) of table 5 which suggests that sickness absence is a more severe problem in German and Dutch firms than in Belgian organisations.

The rank order of the Belgian, German, and Dutch companies observed in the severity rates is repeated in the frequency rates (table 6). The lowest sickness absence frequency is noted among Belgian employees and the highest number of spells is shown by the Dutch workers, whose spell frequency rates are more than $50 \%$ higher than those in the Belgian group.

The third measure used, average duration of a spell, shows a smaller variation and a partly different rank order. It is suggested that in general the longest spells are found among German workers. Some caution is needed here, however, because of the highly skewed distribution of the duration of spells.

\section{CONFOUNDING FACTORS}

Because variables such as sex, age, and occupational status may bias the findings, the effects of these factors on the observed differences need to be evaluated. The 


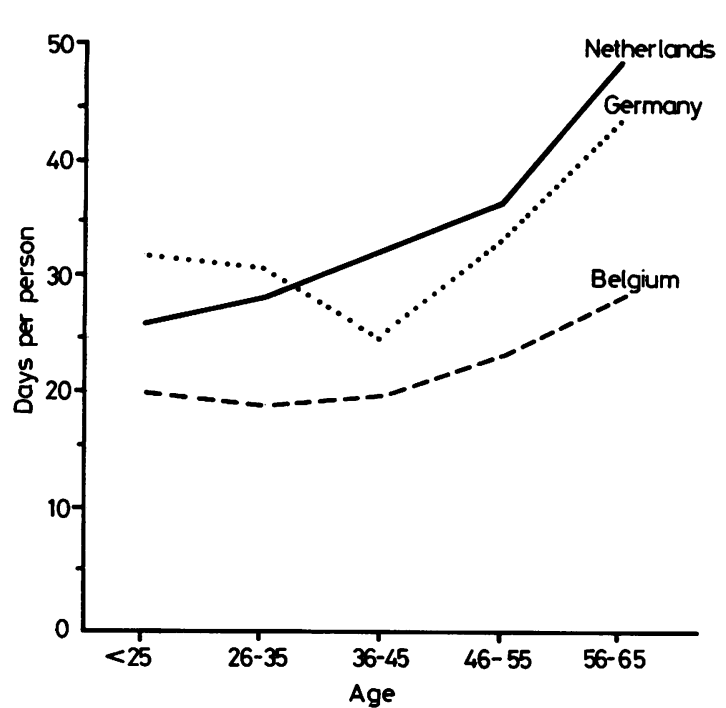

Fig 1 Age specific severity rates in three national groups for 1980 and 1981 .

sex specific figures set out in table 7 indicate that this variable does not dramatically affect the international divergent sickness absence rates. In the male subpopulation the differences in severity and frequency rates are more pronounced.

In the female subpopulation the Belgians again show the lowest sickness rates but only the frequency rates show a rank order consistent with the male subpopulation. Duration rates suggest minor international differences, which is probably due to

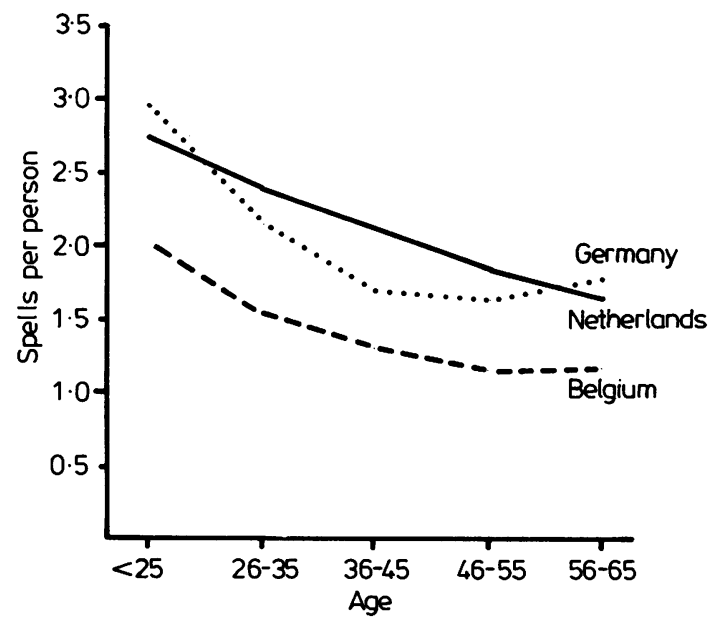

Fig 2 Age specific frequency rates in three national groups for 1980 and 1981.

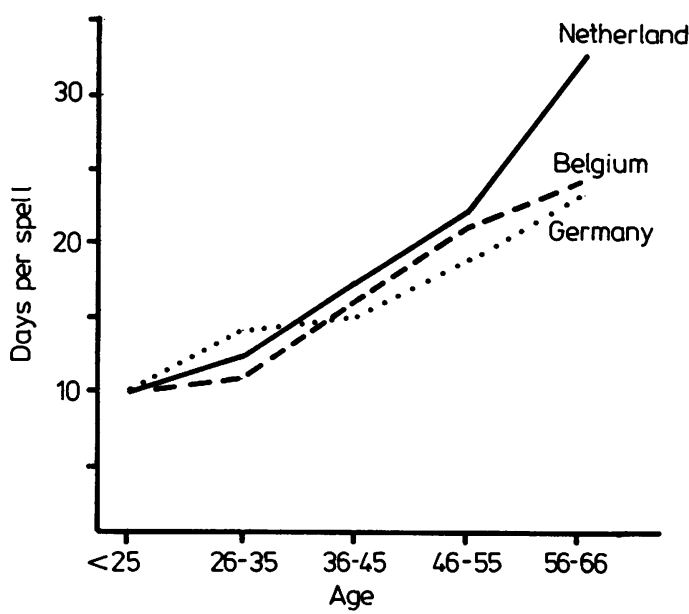

Fig 3 Age specific duration rates in three national groups for 1980 and 1981.

different age structures. Frequency and severity rates are substantially higher among female than among male employees. In all national groups virtually similar relations between sex and absence rates are observed. Comparison of age specific sickness absence rates (figs 1,2 , and 3 ) indicates that the international rank order is little influenced by age. In each of the five age groups Belgian employees generally show the lowest values on the absence measures calculated Except for the two youngest age groups, the highest rates are again found among Dutch employees. Severity rates in Belgian and Dutch employees in the different age group also vary consistently. The average difference in the youngest age group is 6.2 days and 20.1 days in the oldest. The German employees have a sickness rate in between these two, except for the youngest age group which has the highest rate. Furthermore, the figures show in each national group the fairly positive relation of age with severity and duration and the inverse relation of age with spell frequency.

A third variable to be considered here is the occupational status of the employees. Table 8 shows that this variable does not affect the findings fundamentally, although there are differences between the staff and manual workers. Although the original order between the three national groups (B-G-N) is still maintained for each measure, manual workers have consistently higher rates than staff. The Dutch employees show in general about $80 \%$ more spells of sickness absence and $80 \%$ more calendar days yearly lost due to sickness than their Belgian colleagues.

These findings reflect to a great extent the results of the separate analysis on cluster level. Other variables 
Table 8 Average annual sickness absence rates by occupational status in the Belgian, West German, and Dutch group for 1980 and 1981

\begin{tabular}{|c|c|c|c|c|c|c|c|}
\hline National group & No of subjects & $\begin{array}{l}\text { Days per } \\
\text { person }\end{array}$ & Index & $\begin{array}{l}\text { Spells per } \\
\text { person }\end{array}$ & Index & $\begin{array}{l}\text { Duration per } \\
\text { spell }\end{array}$ & Index \\
\hline $\begin{array}{l}\text { Staff } \\
\text { Belgium } \\
\text { Germany } \\
\text { Netherlands } \\
\text { Manual }\end{array}$ & $\begin{array}{r}611 \\
941 \\
1762\end{array}$ & $\begin{array}{l}11.7 \\
19.0 \\
21.9\end{array}$ & $\begin{array}{l}100 \\
162 \\
187\end{array}$ & $\begin{array}{l}1.00 \\
1.58 \\
1.78\end{array}$ & $\begin{array}{l}100 \\
158 \\
178\end{array}$ & $\begin{array}{l}10 \cdot 8 \\
11 \cdot 6 \\
12 \cdot 3\end{array}$ & $\begin{array}{l}100 \\
107 \\
114\end{array}$ \\
\hline $\begin{array}{l}\text { Belgium } \\
\text { Germany } \\
\text { Netherlands }\end{array}$ & $\begin{array}{l}1634 \\
2790 \\
1711\end{array}$ & $\begin{array}{l}24 \cdot 5 \\
35 \cdot 8 \\
44 \cdot 2\end{array}$ & $\begin{array}{l}100 \\
146 \\
180\end{array}$ & $\begin{array}{l}1 \cdot 54 \\
2.00 \\
2 \cdot 52\end{array}$ & $\begin{array}{l}100 \\
130 \\
164\end{array}$ & $\begin{array}{l}15 \cdot 5 \\
17 \cdot 3 \\
17 \cdot 7\end{array}$ & $\begin{array}{l}100 \\
112 \\
114\end{array}$ \\
\hline
\end{tabular}

such as shift, wage group, and nationality were also taken into account, but they do not greatly influence the observed differences. Furthermore, for most variables similar relations with sickness absence are found in the three national groups. For instance, in each national group the elderly, the manual employees, the migrant workers, or the shift workers show higher absence than the younger, the staff employees, the native employees, or the day workers respectively.

\section{STANDARDISATION}

So far the comparisons have been based on unstandardised data, which showed consistent international differences and similar relations between absence rates and population characteristics. It is known, however, that firms (and national groups) may differ in their distribution of variables (table 3), which might bias the differences. Therefore within clusters and national groups a direct standardisation was applied for sex, age, and occupational status. ${ }^{22}$

Results for national groups are presented in table 9 and reflect the findings in the four separate clusters. Standardisation obviously sharpens the international differences (table 9, 2nd column): among the Belgian group the lowest level of sickness absence is found, whereas the Dutch group shows the highest rates both in severity and frequency. German employees now clearly take a middle rank on both absence measures.
The range of differences is becoming quite substantial: compared with their Belgian colleagues, Dutch employees take $70 \%$ more spells of sickness absence a year and about $90 \%$ more calendar days are lost.

To throw more light on these differences, the distribution of the duration of absences was inspected (table 9, 3rd, 4th and 5th columns). Standardised data calculated for three periods (1-7 days, 8-42 days, 43-365 days) showed further differences.

(a) Short term sickness absence (1-7 days) is substantially more frequently observed in the Dutch group than in both other groups. In this respect the Belgian and German figures hardly differ: German employees show the lowest rate of calendar days lost due to short term sickness.

(b) Within the second duration group (8-42 days) differences become more pronounced. The German and Dutch groups have nearly twice as many spells of sickness absence as their Belgian counterpart. Severity rates differ in an identical pattern.

(c) The three groups show overwhelmingly divergent frequency and severity rates of long term sickness absence (43-365 days). The Dutch group has $100 \%$ more spells lasting over six weeks a year than the comparable Belgian group.

These data suggest that the high level of sickness absence (severity, frequency) in the Dutch group is mainly due to spells lasting more than one week, and

Table 9 Average annual severity and frequency rates standardised for sex, age, and occupational status in three national groups for 1980 and 1981

\begin{tabular}{|c|c|c|c|c|c|c|c|c|c|}
\hline & \multirow[t]{2}{*}{ No of subjects } & \multirow{2}{*}{$\begin{array}{l}\text { Total } \\
\text { Days per } \\
\text { person }\end{array}$} & \multicolumn{2}{|c|}{ Spell lasting 1-7 days } & \multicolumn{5}{|c|}{ Spell lasting 8-42 days Spell lasting 43-365 days } \\
\hline & & & Index & $\begin{array}{l}\text { Days per } \\
\text { person }\end{array}$ & Index & $\begin{array}{l}\text { Days per } \\
\text { person }\end{array}$ & Index & $\begin{array}{l}\text { Days per } \\
\text { person }\end{array}$ & Index \\
\hline \multirow[t]{2}{*}{$\begin{array}{l}\text { Belgium } \\
\text { Germany } \\
\text { Netherlands }\end{array}$} & $\begin{array}{l}2245 \\
3730 \\
3477\end{array}$ & $\begin{array}{l}20 \cdot 3 \\
28 \cdot 5 \\
39 \cdot 1\end{array}$ & $\begin{array}{l}100 \\
140 \\
193\end{array}$ & $\begin{array}{l}3 \cdot 8 \\
3 \cdot 3 \\
5 \cdot 1\end{array}$ & $\begin{array}{r}100 \\
87 \\
134\end{array}$ & $\begin{array}{r}7 \cdot 1 \\
14 \cdot 2 \\
14 \cdot 2\end{array}$ & $\begin{array}{l}100 \\
200 \\
200\end{array}$ & $\begin{array}{r}9 \cdot 3 \\
11 \cdot 0 \\
19 \cdot 7\end{array}$ & $\begin{array}{l}100 \\
118 \\
212\end{array}$ \\
\hline & & $\begin{array}{l}\text { Spells per } \\
\text { person }\end{array}$ & Index & $\begin{array}{l}\text { Spells per } \\
\text { person }\end{array}$ & Index & $\begin{array}{l}\text { Spells per } \\
\text { person }\end{array}$ & Index & $\begin{array}{l}\text { Spells per } \\
\text { person }\end{array}$ & Index \\
\hline $\begin{array}{l}\text { Belgium } \\
\text { Germany } \\
\text { Netherlands }\end{array}$ & $\begin{array}{l}2245 \\
3730 \\
3477\end{array}$ & $\begin{array}{l}1 \cdot 32 \\
1 \cdot 86 \\
2 \cdot 25\end{array}$ & $\begin{array}{l}100 \\
141 \\
170\end{array}$ & $\begin{array}{l}0.81 \\
0.93 \\
1.24\end{array}$ & $\begin{array}{l}100 \\
115 \\
153\end{array}$ & $\begin{array}{l}0.42 \\
0.82 \\
0.83\end{array}$ & $\begin{array}{l}100 \\
195 \\
198\end{array}$ & $\begin{array}{l}0.09 \\
0.12 \\
0.19\end{array}$ & $\begin{array}{l}100 \\
133 \\
211\end{array}$ \\
\hline
\end{tabular}


especially those longer than six weeks. The incidence of short term absence is also remarkably high, however. Low rates in short and in long term sickness absence, as well as a high level of absences lasting one to six weeks, may account for the fairly intermediate absence rank for the German group. Finally, the Belgian groups shows the lowest rates of duration, with the exception of the number of days lost due to short term absences.

\section{Discussion}

We realise that the employees we have examined in this study may not accurately represent the whole population of Belgian, German, and Dutch employees. But the following three points should be noted. The international differences in sickness rates in both years are large and consistent. Moreover we recorded and calculated the data in a uniform way. Finally, our results are similar to those of earlier studies. ${ }^{14-18}$ It seems reasonable, therefore, to conclude that the characteristic "country" may be a strong determinant of the level of sickness absence.

Apparently the three countries differ in the legitimation of work incapacity, the level of sick pay, and the criteria of transfer to invalidity insurance (table 3 ). These facts possibly also bring about the difference in the sickness absence rates. In particular we want to emphasise that in the Netherlands the entrance to the disablement insurance is relatively easy and is always preceded by a spell of absence of 52 weeks.

There may also be important differences between the three countries on the factory level-employment policy and absence control, for example. To investigate this further we have begun to interview a personnel manager and the occupational physician in every factory and, if possible, someone on the works council and a production executive. As yet we have not detected a systematic difference between the factories of the three countries in the management of absence and the measures that are taken against it.

It is not clear if the three countries differ in the selection and dismissal of personnel, in labour relations, and in the commitment of the employees to the company. But we hope that we can answer this question when we have worked out the interviews further.

Finally, sociocultural differences (differences in health status and health behaviour or work related values) between the three countries should not be neglected. It will be interesting to find out whether data from available health surveys and investigations on medical consumption reflect the international differences found in this study.

\section{References}

${ }^{1}$ Emanuel $\mathbf{H}$, Halberstadt V, Petersen C. Disability policy in the Netherlands. In: Haveman RH, Halberstadt V, Burkhauser RV, eds. Public policy towards disabled workers; cross-national $\underset{乛}{(\mathbb{D}}$ analysis of economic impacts. Ithaca and London: Cornell ?․ University Press, 1984.

${ }^{2}$ Nederlands Instituut voor Preventieve Gezondheidszorg. Het ziekteverzuim in 1984 (Sickness absence in 1984.) Leiden: Nether- $\bar{\sigma}$ lands Institute for Preventive Health Care, 1985.

${ }^{3}$ SVR (Social Security Council). Maandoverzicht arbeidson- $\bar{O}$ geschikten, oktober $t / m$ december 1984 . (Monthly overview of $\frac{\bar{\sigma}}{7}$ disabled.) Zoetermeer: Sociale Verzekeringsraad, 1985.

${ }^{4}$ Gadourek I. Absences and well-being of workers. Assen: Van Gorcum, 1965.

${ }^{5}$ Philipsen H. Afwezigheid wegens ziekte. (Sickness absence) Gronigen: Wolters-Noordhoff NV, 1969.

${ }^{6}$ Smulders PWG. Bedrijfskenmerken en ziekteverzuim in de jaren $60 \overrightarrow{-}$ en 80; een vergelijkende studie. (Organizational variables and $\vec{\omega}$ sickness absence in the 60s and 80s; a comparative study.) Leiden: Nederlands Instituut voor Preventieve Gezondheidszorg, 1984.

${ }^{7}$ Tordoir WF, Van der Klauw MM, van Maanen-Boekestein CMJ. Gezondheidszorg en lange ziekteduren. (Health care and pro- $\omega$ longing sickness absence.) Leiden: Nederlands Instituut voor $\infty$ Preventieve Gezondheidszorg, 1975.

${ }^{8}$ Soeters J. Patiënt, gezondheidszorg en langdurige ziekte. (Patient, health care and prolonging sickness.) Maastricht: 음 Rijksuniversiteit Limburg, 1983.

${ }^{9}$ Soeters J, Prins R. Health care facilities and work incapacity: a comparison of the situation in the Netherlands with that in six other West European countries. International Social Security Review 1985;2:141-56.

${ }^{10}$ Vroege D. Ziekteverzuim in Nederland, een bedrijfsgeneeskundige $\overrightarrow{+}$ visie. (Sickness absence in the Netherlands; an occupational $\varphi$ medical approach.) Rotterdam: Regionale Bedrijfsgeneeskundige Dienst, 1982.

${ }^{11}$ Salowsky H. Individuelle Fehlzeiten in westlichen Industrieländern. (Individual absenteeism in Western industrialised countries.) Cologne: Institut der Deutschen Wirtschaft, 1980.

12 Salowsky H. Fehlzeiten; ein internationaler Vergleich. (Absenteeism: a cross-national comparison.) Cologne: Institut der $\frac{\mathrm{D}}{\mathbb{D}}$ Deutschen Wirtschaft, 1983.

${ }^{13}$ Fehlzeiten: Vorteile für Japan und USA. (Absenteeism: advantages $\overrightarrow{\vec{F}}$ for Japan and the USA.) Cologne: Institut der Deutschen $\frac{0}{3}$ Wirtschaft, 1984.

${ }^{14}$ Enterline PE. Arbeidsverzuim door ziekte in een aantal westerse landen. (Sickness absence in some West European countries.) Mens en Onderneming 1964;3:162-9.

${ }^{15}$ Enterline PE. Social causes of sick absence. Arch Environ Health 1966;12:467-73.

${ }^{16}$ Taylor PJ. Some international trends in sickness absence 1950-68. Br Med J 1969;iv:705-7.

${ }^{17}$ Taylor PJ. International comparisons of sickness absence. Proc $R$ Soc Med 1972;65:577-86.

${ }^{18}$ Kennedy T. European labor relations; text and cases. Toronto: Lexington Books, 1980.

${ }^{19}$ Smelser NJ. Comparative methods in the social sciences. Englewood Cliffs: Prentice Hall, 1976.

${ }^{20}$ Prins R, Andriessen S. Internationaal Vergelijkend Onderzoek Ziekteverzuim; deel 1: Verzekeringstechnische en arbeids- N rechtelijke aspekten van het ziekteverzuim in België, West- S Duitsland en Nederland. (Cross-national study sickness absence; N part 1: social security and labour juridical aspects of sickness $\mathrm{N}$ absence in Belgium, West Germany and the Netherlands.) $\omega$ Amsterdam: Stichting Coördinatie Communicatie Onderzoek Ziekteverzuim, 1983.

${ }^{21}$ Prins R, Besseling J. International Vergelijkend Onderzoek $\stackrel{0}{\mathrm{C}}$ Ziekteverzuim; deel 2: Analyse van het ziekteverzuim in ges- $\mathbb{D}$ elekteerde Belgische, Westduitse en Nederlandse Bedrijven. (Cross-national study sickness absence; part 2: analysis of sick- $\tau$ ness absence in selected Belgian, West German and Dutch firms.) Amsterdam: Stichting Coördinatie Communicatie Onderzoek $\mathbb{\mathbb { D }}$ Ziekteverzuim (in press).

${ }^{22}$ Anderson S, Auquier A, Hauck WW, Oakes D, Vandaelen W, $\stackrel{\mathbb{Q}}{\varrho}$ Weisberg HI. Statistical methods for comparitive studies. New York: Wiley, 1980. 